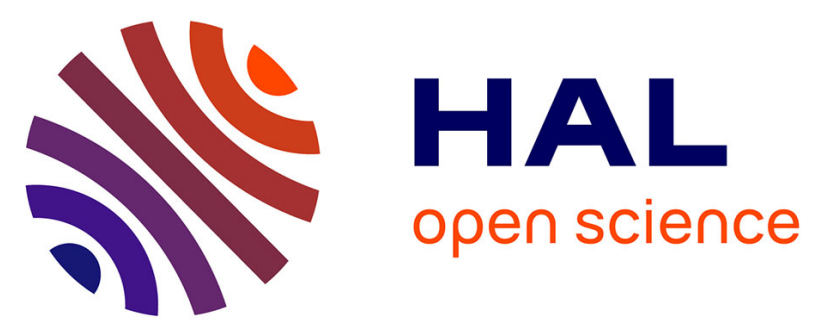

\title{
Safety, tolerability and efficacy of indacaterol, a novel once-daily $\beta$-agonist, in patients with COPD: A 28-day randomised, placebo controlled clinical trial
}

Jutta Beier, Pascal Chanez, J.-B. Jean-Benoit Martinot, A.J.M. Schreurs, R. Ružena Tkáčová, Weibin Bao, Damon Jack, Mark Higgins

\section{To cite this version:}

Jutta Beier, Pascal Chanez, J.-B. Jean-Benoit Martinot, A.J.M. Schreurs, R. Ružena Tkáčová, et al.. Safety, tolerability and efficacy of indacaterol, a novel once-daily $\beta$-agonist, in patients with COPD: A 28-day randomised, placebo controlled clinical trial. Pulmonary Pharmacology \& Therapeutics, 2007, 20 (6), pp.740. 10.1016/j.pupt.2006.09.001 . hal-00499139

\section{HAL Id: hal-00499139 https://hal.science/hal-00499139}

Submitted on 9 Jul 2010

HAL is a multi-disciplinary open access archive for the deposit and dissemination of scientific research documents, whether they are published or not. The documents may come from teaching and research institutions in France or abroad, or from public or private research centers.
L'archive ouverte pluridisciplinaire HAL, est destinée au dépôt et à la diffusion de documents scientifiques de niveau recherche, publiés ou non, émanant des établissements d'enseignement et de recherche français ou étrangers, des laboratoires publics ou privés. 


\section{Author's Accepted Manuscript}

Safety, tolerability and efficacy of indacaterol, a novel once-daily $\beta_{2}$-agonist, in patients with COPD: A 28 day randomised, placebo controlled clinical trial

Jutta Beier, Pascal Chanez, Jean-Benoit Martinot, A.J.M. Schreurs, Ružena Tkáčová, Weibin Bao, Damon Jack, Mark Higgins

PII: $\quad$ S1094-5539(06)00098-8

DOI: $\quad$ doi:10.1016/j.pupt.2006.09.001

Reference: $\quad$ YPUPT 711

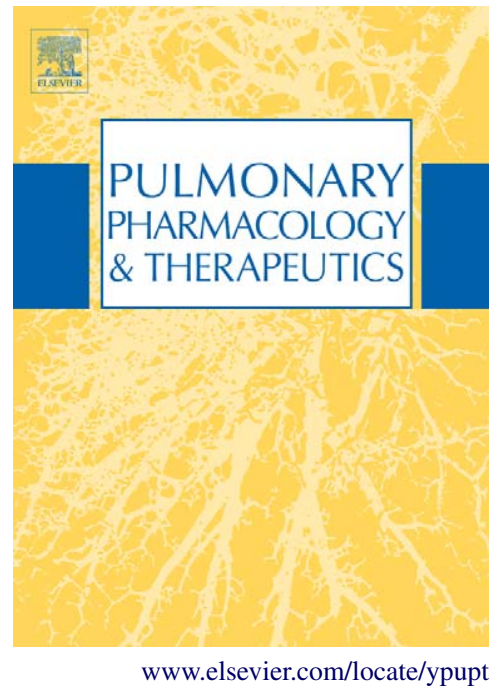

To appear in: Pulmonary Pharmacology \& Therapeutics

Received date: 15 March 2006

Revised date: 5 September 2006

Accepted date: 15 September 2006

Cite this article as: Jutta Beier, Pascal Chanez, Jean-Benoit Martinot, A.J.M. Schreurs, Ružena Tkáčová, Weibin Bao, Damon Jack and Mark Higgins, Safety, tolerability and efficacy of indacaterol, a novel once-daily $\beta_{2}$-agonist, in patients with COPD: A 28-day randomised, placebo controlled clinical trial, Pulmonary Pharmacology \& Therapeutics, doi:10.1016/j.pupt.2006.09.001

This is a PDF file of an unedited manuscript that has been accepted for publication. As a service to our customers we are providing this early version of the manuscript. The manuscript will undergo copyediting, typesetting, and review of the resulting galley proof before it is published in its final citable form. Please note that during the production process errors may be discovered which could affect the content, and all legal disclaimers that apply to the journal pertain. 
Safety, tolerability and efficacy of indacaterol, a novel once-daily $\beta_{2}$-agonist, in patients with COPD: a 28-day randomised, placebo controlled clinical trial

Jutta Beier ${ }^{a, \star}$; Pascal Chanez ${ }^{\text {b }}$ Jean-Benoit Martinott; ${ }^{c}$ A.J.M. Schreurs ${ }^{\text {d }}$; Ružena Tkáčováe; Weibin Baof; Damon Jack ${ }^{\mathrm{f}}$; Mark Higgins ${ }^{g}$.

ainsaf Respiratory Research Institute, Biebricher Allee 34, D-65187 Wiesbaden, Germany

bervice des Maladies Respiratoires, Hôpital Arnaud de Villeneuve, CHU Montpellier, 34059 Montpellier Cedex 1, France

${ }^{c}$ Clinique Ste-Elisabeth, Place Louise Godin, 15, B-5000 Namur, Belgium

dJeroen Bosch Hospital, P.O. Box 90153, 5200ME 's Hertogenbosch, The Netherlands

eDepartment of Pneumology and Tuberculosis, Faculty Hospital L. Pasteur, Rastislavova 43,

SK-041 90 Košice, Slovak Republic

${ }^{f}$ Novartis Pharmaceuticals Corporation, East Hanover, New Jersey, USA

${ }^{9}$ Novartis Horsham Research Centre, Horsham, UK

Type of contribution: Original research

Date of preparation: $\quad 15^{\text {th }}$ March 2006

Number of text pages: $\quad 28$

Number of tables: $\quad 6$

Number of figures: 1

Special instructions: None

*Corresponding author: insaf Respiratory Research, Briebricher Alee 34, 65187, Wiesbaden, Germany. Tel: +49 (0) 611985 4410; fax: +49 (0) 6119854348 


\section{Abstract}

In patients with COPD classified as moderate onwards, Global Initiative for Chronic Obstructive Lung Disease (GOLD) Guidelines recommend regular treatment with one or more long-acting bronchodilators, such as $\beta_{2}$-agonists or anticholinergics. In contrast to currently available long-acting $\beta_{2}$-agonists, which have a duration of action of 12 hours, indacaterol has demonstrated effective 24-hour bronchodilation on once-daily dosing. A double-blind, randomised, placebo-controlled study was conducted to compare the safety, tolerability and efficacy of indacaterol with that of placebo, over a 28-day period, in patients with moderate COPD (as defined by GOLD 2001 criteria; equivalent to moderate-to-severe COPD in the GOLD 2005 criteria).

Patients were randomised 2:2:1 to receive indacaterol $400 \mu \mathrm{g}$ or $800 \mu \mathrm{g}$ or placebo once-daily (between 07:00 and 11:00 h) via a single-dose dry-powder inhaler for 28 days. Assessments included monitoring of adverse events (AEs), blood chemistry (including serum potassium and blood glucose), vital signs (blood pressure and heart rate), electrocardiograms and spirometry.

One hundred and sixty-three patients were randomised, with 155 (95\%) completing the study. There were no statistically significant differences between treatment groups in the overall incidence of AEs, with AEs reported by $35 \%, 51 \%$ and $25 \%$ of patients in the indacaterol $400 \mu \mathrm{g}, 800 \mu \mathrm{g}$ and placebo groups, respectively. The majority of AEs were mild or moderate in severity, and there were no study-drug related serious AEs. There were no statistically significant differences between indacaterol groups and placebo in mean pulse rate and QTc interval, and isolated statistically significant $(p<0.05)$ treatment-placebo differences in mean blood pressure, blood glucose and serum potassium.

There was a statistically significant improvement in $\mathrm{FEV}_{1}$ vs placebo at all postbaseline timepoints for both indacaterol treatment groups; 30 minutes post-dose, adjusted mean $\pm S E F E V_{1}$ indacaterol-placebo differences were: Day 1, 220 $\pm 36 \mathrm{ml}$ and $210 \pm 36 \mathrm{ml}$; Day $14,320 \pm 50 \mathrm{ml}$ and $270 \pm 50 \mathrm{ml}$; Day $28,260 \pm 61 \mathrm{ml}$ and $200 \pm 61 \mathrm{ml}$ for 400 and $800 \mu \mathrm{g}$, 
respectively (all $p<0.01$ vs placebo). Bronchodilation was still apparent after 24 hours, with pre-dose (i.e. trough) adjusted mean $\pm S E \mathrm{FEV}_{1}$ indacaterol-placebo differences of: Day 14, $230 \pm 44 \mathrm{ml}$ and $210 \pm 44 \mathrm{ml}$; Day $28,220 \pm 49 \mathrm{ml}$ and $210 \pm 49 \mathrm{ml}$ for indacaterol $400 \mu \mathrm{g}$ and $800 \mu \mathrm{g}$, respectively (all $p<0.0001$ vs placebo).

Once-daily indacaterol was well tolerated at doses up to $800 \mu \mathrm{g}$ with a good overall safety profile. There was no statistical difference at any dose between the safety of indacaterol and placebo. Furthermore, this study supports the previously demonstrated 24hour bronchodilator efficacy of indacaterol.

Key words: indacaterol; $\beta_{2}$-agonist; bronchodilation; safety; tolerability 


\section{Introduction}

Chronic obstructive pulmonary disease (COPD) is characterised by progressive airway obstruction, resulting in airflow limitation that is only partially reversible [1]. COPD represents a major cause of morbidity and mortality worldwide and is therefore associated with high levels of social and economic burden [1]. The Global Initiative for Chronic Obstructive Lung Disease (GOLD), which provides physicians with guidance on appropriate management of COPD, recommends the implementation of a stepwise treatment plan to manage COPD [1]. Central to control of dyspnoea in COPD are bronchodilators, such as $\beta_{2^{-}}$ agonists: GOLD guidelines recommend regular treatment with one or more long-acting bronchodilators in patients with moderate-to-severe COPD [1]. Two long-acting $\beta_{2}$-agonists are currently available, formoterol and salmeterol, both of which have approximately 12-hour durations of action at recommended doses and therefore must be taken twice daily [2-7]. The only once-daily bronchodilator available at present is the anticholinergic tiotropium, which has a duration of action of at least 24 hours $[8,9]$.

Indacaterol is a novel once-daily $\beta_{2}$-agonist being developed for the treatment of COPD and asthma. Preclinical study results suggest that indacaterol has a longer duration of action than either formoterol or salmeterol, with a rapid onset of action, and a potentially greater cardiovascular safety margin compared with formoterol or salmeterol, for a given degree of bronchodilator activity [10]. In clinical studies in patients with asthma, indacaterol has demonstrated effective 24-hour bronchodilation with a rapid onset of action and was shown to be well tolerated with a good overall safety profile $[11,12]$.

The primary objective of the current study was to compare the safety and tolerability of once-daily administration of two doses of indacaterol (400 $\mu \mathrm{g}$ and $800 \mu \mathrm{g})$ with that of placebo, over a 28-day period, in patients with moderate COPD. Particular attention was paid to the key safety parameters for this class of drug, namely serum potassium, blood glucose, heart rate, blood pressure, QTc interval and adverse events (AEs) such as tremor, headache and nervousness. A secondary objective was to explore the bronchodilator efficacy of indacaterol, in terms of the effects on lung function. 


\section{Methods}

\subsection{Design}

This was a phase II, multinational, double-blind, randomised, placebo-controlled, parallel-group study in patients with COPD. Enrolled patients entered a 2-week run-in period and were subsequently randomised to receive 28 days of study treatment, with a 7 -day follow-up period to monitor AEs after study-drug cessation. The study was conducted according to Good Clinical Practice Guidelines and in accordance with the Declaration of Helsinki (1964 and subsequent revisions). The study received Institutional Review Board approval, and all patients gave written informed consent prior to the start of the study.

\subsection{Inclusion and exclusion criteria}

Male and female patients aged $40-75$ years with a diagnosis of moderate COPD as defined by the 2001 GOLD Guidelines [13] were eligible for enrolment, provided they had a smoking history of at least 10 pack-years and their forced expiratory volume in one second $\left(\mathrm{FEV}_{1}\right)$ was $<70 \%$ of their forced vital capacity (FVC). In addition, patients were required to have an $\mathrm{FEV}_{1} 30-70 \%$ of the Quanjer predicted normal value [14], when measured after a washout period of at least 6 hours during which no short-acting $\beta_{2}$-agonist was inhaled, and at least 24 hours after the last use of a long-acting $\beta_{2}$-agonist.

Patients were excluded if they had a recent respiratory tract infection or COPD exacerbation, if they had a history of asthma (blood eosinophil count $>500 / \mathrm{mm}^{3}$ or an onset of symptoms prior to the age of 40 years), or if they had a significant unstable cardiovascular or metabolic comorbidity. Patients were also excluded if they had used any of the following: tiotropium bromide within 7 days of run-in or ipratropium bromide, inhalers combining inhaled corticosteroids and $\beta_{2}$-agonists, or long-acting $\beta_{2}$-agonists within 24 hours of run-in. 


\subsection{Study treatment}

Patients were randomised $(2: 2: 1)$ to receive indacaterol $400 \mu \mathrm{g}$ or $800 \mu \mathrm{g}$ or placebo, once daily via a single-dose dry-powder inhaler. Treatments were administered in the morning (between 07:00 and 11:00 h) via sequential inhalation from two dry powder capsules, each delivering indacaterol $200 \mu \mathrm{g}, 400 \mu \mathrm{g}$ or placebo, respectively, per capsule. Dose selection was based on a previous study in patients with bronchial asthma where an effective dose was considered to be in the range of $200-400 \mu \mathrm{g}$ [11]. The present study was therefore designed to examine the safety, tolerability and efficacy of doses considered up to approximately twice the anticipated therapeutic dose for asthma.

Inhaled salbutamol was provided as rescue medication to be used as needed throughout the run-in and treatment periods. Rescue salbutamol was not to be taken within 6 hours of the start of a study visit unless necessary. Prior to the run-in period, those patients using long-acting $\beta_{2}$-agonists were permitted regular use of salbutamol for the duration of the run-in period, and for those using inhalers combining inhaled corticosteroids and $\beta_{2}$-agonists, the steroid component was replaced with equivalent inhaled corticosteroid monotherapy. Patients on inhaled corticosteroid monotherapy prior to run-in continued on their pre-study regimen. During the treatment phase, all patients received the same inhaled corticosteroid regimen as they received during the run-in period. Patients were not permitted to use any of the following medications during the run-in or treatment periods: tiotropium bromide, ipratropium bromide, combination formulations of $\beta_{2}$-agonists and inhaled corticosteroids, long-acting $\beta_{2}$-agonists or short-acting $\beta_{2}$-agonists (other than salbutamol as above).

Patients were permitted to use theophyllines during the study in recommended and constant dose regimens, providing treatment had been stabilised for at least one month prior to the start of the run-in period. However, such medication was to be withheld on the morning of scheduled clinic visits until after completion of the last spirometry measurement at those visits.

\subsection{Assessments}


Safety assessments included monitoring of AEs throughout the study and regular monitoring of haematology, blood chemistry (with particular attention to serum potassium and blood glucose), urinalysis, vital signs and electrocardiograms (ECGs). Efficacy assessments included the monitoring of lung function throughout the study.

On Days 1, 14 and 28 of study treatment, the results of the following assessments were recorded pre- and 60 minutes post-dose: haematology, blood chemistry (including serum potassium and blood glucose), urinalysis, pulse rate, systolic and diastolic blood pressure, and ECGs. Both Bazett's formula $(\mathrm{QTC}=\mathrm{QT} / \sqrt{\mathrm{RR}})$ and Fridericia's formula $\left(\mathrm{QTc}=\mathrm{QT} / /^{3} \sqrt{\mathrm{R} R}\right)$ were used to calculate $\mathrm{QTc}$ interval.

Spirometry $\left(\mathrm{FEV}_{1}, \mathrm{FVC}\right.$ and forced expiratory flow $\left.\left[\mathrm{FEF}_{25-75 \%}\right]\right)$ was assessed preand 30 minutes post-dose on Days 1, 14 and 28. Pulmonary function tests were evaluated with the use of calibrated spirometry. All pulmonary function testing was performed according to European Respiratory Society standards with the patients in a sitting position. Tests were performed at the same time of day under standard conditions by the same technician in order to ensure consistent technique. Three technically acceptable measurements were performed for each patient and the highest value was used in the analyses. The change and percentage increase in $\mathrm{FEV}_{1}$ from baseline were compared across the treatment groups. In addition, the use of rescue medication was examined on Days 1,14 and 28 by asking the patient to provide an estimate of average daily use since the last visit. Records of study medication use, dosages administered and intervals between visits were kept during the study; patients were asked to return all unused medication at the end of the study.

\subsection{Statistical analyses}

Adverse events which began or worsened between starting study treatment and the end of follow-up were summarised. The incidences of tremor, headache and nervousness, which are recognized AEs for the class of drug, were presented with $95 \%$ confidence 
intervals (computed as exact 95\% confidence intervals based on the binomial distribution) for each treatment group.

Key variables (serum potassium, blood glucose, pulse rate, systolic and diastolic blood pressure, QTc interval and $\mathrm{FEV}_{1}$ ) were analysed using a two-way analysis of covariance (ANCOVA) model, with country and treatment as factors and the baseline value of the variable as a covariate. The country effect was treated as fixed and interactions or other effects were not investigated. This type of model provided comparisons between treatment groups at each timepoint while adjusting appropriately for any baseline differences in the variable of focus (note that for all variables analysed in this way there were no significant differences at baseline between active groups and placebo). In each case, the ANCOVA model did not employ repeated measures, but rather applied at each timepoint separately.

Spirometry data other than $\mathrm{FEV}_{1}$ (i.e. $\mathrm{FVC}$ and $\mathrm{FEF}_{25-75 \%}$ ) were summarised over time, with no additional statistical analyses prespecified. Salbutamol rescue medication was summarised by the average daily number of puffs used between visits, again with no additional statistical analyses prespecified. Safety variables were analysed using results from the safety population (all randomised patients who received at least one dose of study medication), whereas exploratory efficacy analyses were performed using results from the intent-to-treat population (all randomised patients who received at least one dose of study medication and had at least one post-dose $\mathrm{FEV}_{1}$ measurement). 


\section{Results}

\subsection{Patient characteristics}

Patients were recruited from 22 centres in five countries: Belgium, Germany, France, the Netherlands and Slovakia. In total, 253 patients were screened, of whom 163 met the inclusion criteria and were randomised to study treatments; $155(95 \%)$ completed the study. All randomised patients received at least one dose of the study drug. Of the eight patients who did not complete the study, five withdrew because of protocol violations, 2 withdrew because of AEs (see later for further details) and one patient withdrew consent. Patients were almost exclusively Caucasian (99.4\%), aged 40-75 years, with a mean duration of COPD of 7 years (Table 1).

Baseline patient demographics, lung function and salbutamol use were well balanced, with no statistically significant differences between treatment groups. Although mean $\mathrm{FEV}_{1}$ reversibility appeared to be relatively high (mean values ranging between 11.2 and $12.7 \%$ ), patients with a history of asthma had been excluded from the study. Compliance to treatment was high and similar among treatment groups, with patients in the indacaterol $400 \mu \mathrm{g}$ and $800 \mu \mathrm{g}$ and placebo groups receiving treatment for a mean $\pm \mathrm{SD}$ of $27.0 \pm 4.7,26.9 \pm 4.5$ and $27.1 \pm 2.8$ days, respectively.

\subsection{Safety}

The overall $A E$ profile did not suggest any specific toxicity towards a major organ system, and the majority of AEs experienced were mild or moderate in severity. There were no statistically significant differences between treatment groups in the overall AE incidence, with AEs reported by $35.3 \%$ (95\% Cl: $24.1 \%, 47.8 \%), 50.7 \%(38.2 \%, 63.2 \%)$ and $25.0 \%$ $(10.7 \%, 44.9 \%)$ of patients taking indacaterol $400 \mu \mathrm{g}$ and $800 \mu \mathrm{g}$ and placebo, respectively (Table 2). The most frequent AEs were typical of this patient population (respiratory, thoracic and mediastinal [excluding infections]). Of the AEs that could be considered to be $\beta_{2}$-agonist class effects, there was one case of tremor reported in each of the indacaterol treatment groups and five patients (7.5\%) in the $800 \mu \mathrm{g}$ group reported headache. 
Gough was the most frequent $A E$ in the indacaterol treatment groups The difference between treatment groups in the incidence of AEs was largely due to an increased incidence of cough in the indacaterol groups, reported by $10(14.7 \%)$ and $19(28.4 \%)$ patients in the indacaterol 400 and $800 \mu \mathrm{g}$ groups, respectively, compared with no patients in the placebo group. The majority of cough events were of mild severity, with onset associated with the initial dose of study medication. The incidence of cough declined at subsequent visits, such that at the final dosing visit (Day 28) no patients in any treatment group coughed after study drug administration.

Three patients $(4.4 \%)$ in the indacaterol $400 \mu \mathrm{g}$ group and two $(7.1 \%)$ in the placebo group (compared to no patients in the indacaterol $800 \mu \mathrm{g}$ group) experienced an exacerbation of their COPD. One of the events in the indacaterol $400 \mu \mathrm{g}$ group was classified as a serious $A E$; this occurred 1 week after the patient finished taking study medication. One of the other patients in the indacaterol $400 \mu \mathrm{g}$ group withdrew from the study as a result of an exacerbation. None of the COPD exacerbations was considered related to study drug treatment.

One other AE led to discontinuation. This also occurred in the indacaterol $400 \mu \mathrm{g}$ group, in which a patient developed a severe throat irritation which was considered to be related to study medication.

One serious AE occurred in the indacaterol $400 \mu \mathrm{ng}$ group - a COPD exacerbation 1 week after the patient finished taking study medication - however, this was not considered to be related to the study drug. Two AEs led to discontinuation, both in the indacaterol $400 \mathrm{ng}$ group: one patient experienced a COPD exacerbation which was not suspected to be related to the study drug and one patient developed a severe throat irritation which was considered to be related to study medication.

\subsection{Cardiovascular safety}

Pulse rate and blood pressure results are shown in Table 3. There were no statistically significant differences in pulse rate between indacaterol and placebo groups at 
any timepoint. Mean pulse rate was significantly lower in the indacaterol $400 \mu \mathrm{g}$ group compared to the indacaterol $800 \mu \mathrm{g}$ group at 60 min post-dose on Day $14(p=0.015)$, and predose on Day 28 ( $p=0.022$; Table 3). High pulse rates (i.e. $>90$ b.p.m.) were observed in $14.7 \%, 14.9 \%$ and $17.9 \%$ of patients in the indacaterol $400 \mu \mathrm{g}$ and $800 \mu \mathrm{g}$, and placebo groups, respectively; no patient had a low pulse rate (i.e. $<40$ b.p.m.).

The only statistically significant difference between groups in mean systolic blood pressure was seen with indacaterol $800 \mu \mathrm{g}$ compared with placebo $60 \mathrm{~min}$ post-dose on Day $14(p=0.003 ;$ Table 3). For mean diastolic blood pressure, the only statistically significant differences were between indacaterol $400 \mu \mathrm{g}$ and placebo 60 min post-dose on Day 14 ( $p=0.048)$, and between indacaterol $400 \mu \mathrm{g}$ and $800 \mu \mathrm{g}$ predose on Day $28(p=0.029)$.

There was no statistically significant difference between treatments in mean QTc interval at any timepoint using either formula (Table 4). Using Bazett's formula, only one patient taking indacaterol $800 \mu \mathrm{g}$ and one patient taking placebo had an increase in QTC interval >60 ms from baseline. Using Fridericia's formula, one patient in the indacaterol $400 \mu \mathrm{g}$ group and three in the $800 \mu \mathrm{g}$ group had QTc interval values above the normal range, and one patient in the $800 \mu \mathrm{g}$ group had an increase in QTc interval $>60 \mathrm{~ms}$ from baseline.

\subsection{Laboratory variables and haematology}

Post-dose on Day 1, but not on subsequent visits, mean serum potassium was significantly lower in the indacaterol $800 \mu \mathrm{g}$ group compared to the indacaterol $400 \mu \mathrm{g}$ $(p=0.031)$ and placebo groups $(p=0.029 ;$ Table 5$)$. One patient in the indacaterol $800 \mu \mathrm{g}$ group experienced at one timepoint a post-baseline value of $3.4 \mathrm{mmol} / \mathrm{l}$ that occurred predose on Day 28.

The only statistically significant difference between groups in mean blood glucose was between indacaterol $800 \mu \mathrm{g}$ and placebo predose on Day $14(p=0.009$; Table 5). Blood glucose values above the normal range (i.e. $>7.7 \mathrm{mmol} / \mathrm{l}$ ) were reported by $5(7.4 \%$ ), ten 
$(14.9 \%)$ and six (21.4\%) patients in the indacaterol $400 \mu \mathrm{g}$ and $800 \mu \mathrm{g}$ and placebo groups, respectively.

There was no evidence of any drug- or dose-related effects on the majority of the standard haematological tests in any treatment group, and no haematology-related AEs were reported.

\subsection{Efficacy}

There was a marked improvement in $\mathrm{FEV}_{1}$ in both indacaterol treatment groups at all visits, with a statistically significant improvement vs placebo at all post-baseline timepoints $(p<0.01)$ (Figure 1). Since the predose $\mathrm{FEV}_{1}$ assessment on Days 14 and 28 was approximately 24 hours after inhalation of the previous dose of study medication, this was effectively the 'trough' value, and provided evidence of the duration of action of indacaterol.

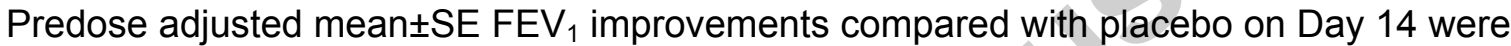
$230 \pm 44 \mathrm{ml}$ and $210 \pm 44 \mathrm{ml}$ for indacaterol $400 \mu \mathrm{g}$ and $800 \mu \mathrm{g}$, respectively $(p<0.0001 \mathrm{vs}$ placebo for both). Corresponding values on Day 28 were $220 \pm 49 \mathrm{ml}$ and $210 \pm 49 \mathrm{ml}$ $(p<0.0001$ vs placebo for both).

At 30 minutes post-dose, adjusted mean $\pm S E F E V_{1}$ improvements compared with placebo for indacaterol $400 \mu \mathrm{g}$ and $800 \mu \mathrm{g}$, respectively, were: Day 1, 220 $\pm 36 \mathrm{ml}$ and $210 \pm 36 \mathrm{ml}(p<0.0001 \mathrm{vs}$ placebo for both); Day $14,320 \pm 50 \mathrm{ml}$ and $270 \pm 50 \mathrm{ml}(p<0.0001 \mathrm{vs}$ placebo for both); Day $28,260 \pm 61 \mathrm{ml}(p<0.0001$ vs placebo) and $200 \pm 61 \mathrm{ml}(p=0.001 \mathrm{vs}$ placebo).

Indacaterol, but not placebo, demonstrated statistically significant improvements in $\mathrm{FEV}_{1}$ from baseline to 30 minutes post-dose on Days 1, 14 and 28. Post-dose adjusted mean (95\% confidence interval) improvements from baseline in $\mathrm{FEV}_{1}$ (in $\mathrm{ml}$ ) for indacaterol $400 \mu \mathrm{g}$ and $800 \mu \mathrm{g}$ and placebo, respectively were: Day 1, 260 (220, 300), 240 (200, 280), 30 (-30, 90); Day 14, 320 (270, 370), 270 (210, 320), 0 (-90, 80); Day 28, $320(260,380)$, $260(200,320), 60(-40,160)$. The mean percentage increase in $\mathrm{FEV}_{1}$ from baseline was consistently higher for the indacaterol treatment groups vs placebo at each post-dose 
timepoint, with the highest proportion of patients with increases $>17 \%$ from baseline in the $400 \mu \mathrm{g}$ group (30 minutes post-dose on Day 28, 44 [71.0\%], 30 [48.4\%] and 3 [13.0\%] patients in the indacaterol 400 and $800 \mu \mathrm{g}$ and placebo groups, respectively, demonstrated $\mathrm{FEV}_{1}$ increases from baseline $>17 \%$ ).

At all post-baseline timepoints, mean $\mathrm{FVC}$ and $\mathrm{FEF}_{25-75 \%}$ were greater than baseline in both indacaterol groups; values in the placebo group were below baseline at a number of post-baseline timepoints (Table 6). In all groups, the number of patients who required rescue salbutamol medication decreased over the course of the study. According to patient estimates, the number of patients not using salbutamol increased from $18 \%$ to $60 \%$ in the indacaterol $400 \mu \mathrm{g}$ group, from $16 \%$ to $42 \%$ in the indacaterol $800 \mu \mathrm{g}$ group, and from $11 \%$ to $36 \%$ in the placebo group. 


\section{Discussion}

The present study showed that in patients with COPD, once-daily indacaterol at doses up to $800 \mu \mathrm{g}$ per day had a good safety profile, was well tolerated and demonstrated 24-hour bronchodilation. As $800 \mu \mathrm{g}$ represents $2-4$ times the therapeutic dose suggested by earlier studies [15], these results imply that the therapeutic window for indacaterol may be wide. Although the population of this study was originally defined as having moderate COPD, following an update of the GOLD criteria, these patients would now be classified as having moderate-to-severe COPD [1]. Current GOLD Guidelines recommend the use of long-acting bronchodilators for the treatment of patients with COPD classified as moderate onwards, therefore indacaterol, as a novel long-acting $\beta_{2}$-agonist, has the potential to extend the options available for the treatment of such patients [1]. Salmeterol and formoterol, the two currently available long-acting $\beta_{2}$-agonists, are recommended to be used twice daily as they have approximately 12-hour durations of action at recommended doses [2-7]. Previous studies have shown that patients prefer once-daily dosing regimens over twice-daily regimens [16], which suggests the possibility of improved patient compliance with once-daily indacaterol. In addition, tiotropium, the only once-daily bronchodilator available at present, has been shown to provide superior improvements in lung function and health-related quality of life when compared to four-times-daily dosing with the short-acting anticholinergic ipratropium $[8,9]$.

Overall, indacaterol was well tolerated in the current study with no statistically significant differences between treatment groups in the overall incidence of AEs. There was no indication of a relation between the incidence of individual AEs and dose. The only exceptions were the higher number of headaches reported in the indacaterol $800 \mu \mathrm{g}$ group and the higher incidence of cough in both indacaterol groups compared with placebo. The fact that no patients receiving placebo reported cough may be partly the result of chance, since fewer patients received placebo than indacaterol owing to the 2:2:1 randomisation. However, most of the episodes of cough were mild in severity and occurred after the first inhalation of study medication, with incidence declining at subsequent visits such that no 
patients coughed after study drug administration on the final visit. The incidence of cough is therefore not expected to affect the overall tolerability of indacaterol. The characteristics of the cough have been investigated further in other studies: It is of short duration (typically lasting less than two minutes post-dose) and is not associated with bronchospasm. These results will be included in future publications. There were no serious AEs considered to be related to the study drug, and only one patient discontinued because of an AE suspected of being related to indacaterol. In addition, AEs typical of the $\beta_{2}$-agonist class were generally mild in severity and low in overall incidence, although, as expected, they occurred in the indacaterol treatment groups more frequently than with placebo. The good overall tolerability profile of indacaterol is further supported by the high level of compliance to treatment in this study, and by the very low drop-out rate. In addition, both doses of indacaterol demonstrated a good overall safety profile, with no clinically relevant differences between treatment groups in any of the cardiovascular or biochemical variables assessed.

This study was designed primarily to investigate the safety and tolerability of indacaterol and therefore was not powered to allow definitive conclusions about efficacy. However, exploratory analyses showed statistically superior increases in $\mathrm{FEV}_{1}$ for both indacaterol doses compared with placebo, at all post-baseline timepoints, including predose (or trough). This suggests that tolerance to the bronchodilator effects of indacaterol did not develop over 28 days. These results are consistent with those previously observed for indacaterol in a 28-day study in patients with asthma, in which there was no loss of efficacy over the duration of the study [12]. In the current study, clinically relevant improvements in FEV 1 were apparent pre-dose on Days 14 and 28, approximately 24 hours after the previous dose, demonstrating the 24-hour duration of action of indacaterol and supporting the appropriateness of a once-daily dosing regimen. This sustained efficacy has been demonstrated previously in a study in patients with asthma in which single doses of indacaterol as low as $200 \mu \mathrm{g}$ provided 24-hour bronchodilator efficacy [11]. Further to the spirometry results, the greater reduction in rescue medication use reported in the indacaterol groups may also reflect improved control of dyspnoea with indacaterol. 
Long-acting $\beta_{2}$-agonists administered at higher than recommended doses have previously been associated with changes in heart rate, QTc interval and serum potassium and glucose levels, in patients and healthy volunteers [17-23]. The current study was therefore specifically designed to monitor and assess changes in these variables. There were no clinically relevant differences in serum potassium or blood glucose observed between groups, with isolated statistically significant differences only recorded at two timepoints, both with indacaterol $800 \mu \mathrm{g}$. Over the duration of the study, there were no clinically significant effects on pulse rate or blood pressure and no statistically significant differences between indacaterol groups and placebo in mean QTc intervals. Both doses of indacaterol therefore demonstrated a favourable clinical cardiovascular safety profile, supporting data from a previous study in patients with asthma in which indacaterol doses as high as $600 \mu \mathrm{g}$ were not associated with cardiovascular adverse effects [12]. Overall, the current study does not raise any concerns over the effect of indacaterol on these specific safety variables.

In conclusion, the present study demonstrates that the novel once-daily $\beta_{2}$-agonist indacaterol is well tolerated at doses up to $800 \mu \mathrm{g}$ with a good overall safety profile. Furthermore, these results support the previously demonstrated 24-hour bronchodilator efficacy of once-daily indacaterol. 


\section{Acknowledgements}

The authors would like to thank the investigators and staff at the study centres as follows:

Belgium: Prof. M Decramer, Dienst Pneumologie, Leuven; Prof. Vincken, Dienst

Pneumologie, Jette; Dr J-B Martinot, Clinique Ste-Elisabeth, Namur; Dr V Ninane, Service de Pneumologie, Bruxelles; Dr R Peché, CHU Vésale, Montigny-le-Tilleul; Dr P Ortmanns, Longziekten - Allergie, Kontich.

France: Dr P Chanez, Service des Maladies Respiratoires, Hôpital Arnaud de Villeneuve, Montpellier; Dr T Duvauchelle, Aster Cephac, Paris; Dr B Aguilaniu, Lab Physiopathologie, Grenoble.

Germany: Dr J Beier, insaf Respiratory Research Institute, Wiesbaden; Dr K Richter, Pneumologische Forschungsinstitut, Hamburg; Dr S Schmidtmann, Plaza Marzahn, Berlin; Dr W Schroeder-Babo, Praxis Dr Schroeder-Babo, Gelnhausen; Prof. A Gillissen, RobertKoch-Hospital, Leipzig; PD Dr J Ficker, Klinikum der Stadt Nuernberg, Nuernberg; Dr W Zachgo, Praxis Dr. Zachgo, Geesthacht; Dr W Schuermann, Praxis Dr. Schuermann, Marburg.

The Netherlands: Prof. Dr PNR Dekuijzen, UMC St Radboud, Nijmegen; Dr R Aalbers, Martini Ziekenhuis, Groningen; Dr PB Luursema, Het Nieuwe Spittaal, Zutphen; Dr AJM Schreurs, Jeroen Bosch Hospital, Hertogenbosch.

Slovak Republic: Dr R Tkacova, Klinika Pneumologie a Ftizeologie, Fakultna nemocnica L. Pasteura, Kosice; Dr L Chovan, Klinika Pneumologie a Ftizeologie SPAM, Bratislava; Dr J Mazal, NsP FDR Banska Bystrica TaRCH, Banska Bystrica.

The authors were assisted by professional medical writers, Sarah Filcek and David Young, in the preparation of this text. 


\section{References}

[1] Global Initiative for Chronic Obstructive Lung Disease. Global Strategy for the Diagnosis, Management and Prevention of Chronic Obstructive Pulmonary Disease. NHLBI/WHO workshop report. Bethseda, National Heart, Lung, and Blood Institute. April 2001: Updated 2005. GOLD website (www.goldcopd.com).

[2] Schaanning J, Vilsvik J, Henriksen AH, Bratten G. Efficacy and duration of salmeterol powder inhalation in protecting abainst exercise-induced bronchoconstriction. Ann Allergy Asthma Immunol 1996;76:57-60.

[3] Brogden RN, Faulds D. Salmeterol xinafoate. A review of its pharmacological properties and therapeutic potential in reversible obstructive airways disease. Drugs 1991;42:895-912.

[4] Wallin A, Sandstrom T, Rosenhall L, Melander B. Time course and duration of bronchodilatation with formoterol dry powder in patients with stable asthma. Thorax. 1993;48:611-614.

[5] Quebe-Fehling E, Brambilla R, Bromly CL, Fishwick K, Walters EH, Hendrick DJ. The duration of action of inhaled formoterol dry powder. Br J Clin Pract 1996;50:446-449.

[6] Sykes AP, Ayres JG. A study of the duration of the bronchodilator effect of 12 micrograms and 24 micrograms of inhaled formoterol and 200 micrograms inhaled salbutamol in asthma. Respir Med 1990;84:135-138.

[7] Bartow RA, Brogden RN. Formoterol. An update of its pharmacological properties and therapeutic efficacy in the management of asthma. Drugs 1998;55:303-322.

[8] Vincken W, van Noord JA, Greefhorst AP, Bantje TA, Kesten S, Korducki L, Cornelissen PJ, on behalf of the Dutch/Belgian Tiotropium Study Group. Improved health outcomes in patients with COPD during 1 yr's treatment with tiotropium. Eur Respir J 2002;19:209-216.

[9] Casaburi R, Mahler DA, Jones PW, Wanner A, San Pedro G, ZuWallack RL, Menjoge SS, Serby CW, Witek T Jr. A long-term evaluation of once-daily inhaled tiotropium in chronic obstructive pulmonary disease. Eur Respir J 2002;19:217-224. 
[10] Battram C, Charlton SJ, Cuenoud B, Dowling MR, Fairhurst RA, Farr D, et al. In vitro and in vivo pharmacological characterization of 5-[(R)-2-(5,6-diethyl-indan-2-ylamino)1-hydroxy-ethyl]-8-hydroxy-1H-quinolin-2-one (indacaterol), a novel inhaled beta(2) adrenoceptor agonist with a 24-h duration of action. J Pharmacol Exp Ther 2006;317:762-70.

[11] Beeh K-M, Derom E, Kanniess F, Cameron R, vanAs A. Indacaterol: the first oncedaily $\beta_{2}$-agonist with 24-hour bronchodilation. Eur Respir J 2005;26(Suppl. 49):253s, P1725.

[12] Chuchalin AG, Tsoi AN, Richter K, Arievich H, Cameron R, Bao W, vanAs A. Cardiovascular safety of indacaterol, a novel 24 -hour $\beta_{2}$-agonist, in patients with stable asthma. Eur Respir J 2005;26(Suppl. 49):253s, P1728.

[13] Global Initiative for Chronic Obstructive Lung Disease. Global Strategy for the Diagnosis, Management and Prevention of Chronic Obstructive Pulmonary Disease. NHLBI/WHO workshop report. Bethseda, National Heart, Lung, and Blood Institute. April 2001:GOLD website (www.goldcopd.com).

[14] Quanjer PH, Tammeling GJ, Cotes JE, Pedersen OF, Reslin R, Yernault. Lung volumes and forced ventilatory flows. Eur Respir J 1993;6(Suppl 16):5-40.

[15] Kanniess F, Cameron R, Owen R, Higgins M. Indacaterol, a novel 24-hour $\beta_{2}$-agonist, demonstrates 24-hour efficacy and is well tolerated in patients with asthma: a multipledose, dose-ranging study. Eur Respir J 2005;26(Suppl. 49):253s, P1729.

[16] Venables TL, Addlestone MB, Smithers AJ, Blagden MD, Weston D, Gooding, T Carr EP on behalf of the PROOF research group. A comparison of the efficacy and patient acceptability of once daily budesonide via turbohaler and twice daily fluticasone propionate via disc-inhaler at an equal daily dose of $400 \mu \mathrm{g}$ in adult asthmatics. British Journal of Clinical Research 1996;7:15-32.

[17] Bennett JA, Smyth ET, Pavord ID, Wilding PJ, Tattersfield AE. Systemic effects of salbutamol and salmeterol in patients with asthma. Thorax 1994;49:771-774. 
[18] Bennett JA, Tattersfield AE. Time course and relative dose potency of systemic effects from salmeterol and salbutamol in healthy subjects. Thorax 1997;52:458-464.

[19] Maconochie JG, Forster JK. Dose-response study with high-dose inhaled salmeterol in healthy subjects. Br J Clin Pharmacol 1992;33:342-345.

[20] Bremner P, Woodman K, Burgess C, Crane J, Purdie G, Pearce N, et al. A comparison of the cardiovascular and metabolic effects of formoterol, salbutamol and fenoterol. Eur Respir J 1993;6:204-210.

[21] Burgess C, Ayson M, Rajasingham S, Crane J, Della CG, Till MD. The extrapulmonary effects of increasing doses of formoterol in patients with asthma. Eur J Clin Pharmacol $1998 ; 54: 141-147$.

[22] Maesen FP, Costongs R, Smeets JJ, Brombacher PJ, Zweers PG. The effect of maximal doses of formoterol and salbutamol from a metered dose inhaler on pulse rates, ECG, and serum potassium concentrations. Chest 1991;99:1367-1373.

[23] Totterman KJ, Huhti L, Sutinen E, Backman R, Pietinalho A, Falck M, et al. Tolerability to high doses of formoterol and terbutaline via Turbuhaler for 3 days in stable asthmatic patients. Eur Respir J 1998;12:573-579. 
Table 1

Patient demographics and baseline characteristics

\begin{tabular}{|c|c|c|c|}
\hline Variable & $\begin{array}{c}\text { Indacaterol } 400 \mu \mathrm{g} \\
(n=68)\end{array}$ & $\begin{array}{c}\text { Indacaterol } 800 \mu \mathrm{g} \\
(n=67)\end{array}$ & $\begin{array}{c}\text { Placebo } \\
(n=28)\end{array}$ \\
\hline \multicolumn{4}{|l|}{ Age (years) } \\
\hline Mean (SD) & $59.6(8.5)$ & $61.2(8.9)$ & $61.1(7.0)$ \\
\hline Range & $41.0-75.0$ & $40.0-75.0$ & $50.0-74.0$ \\
\hline \multicolumn{4}{|l|}{ Age category (years), $n(\%)$} \\
\hline $40-65$ & $47(69.1)$ & $44(65.7)$ & $19(67.9)$ \\
\hline 66-75 & $21(30.9)$ & $23(34.3)$ & $9(32.1)$ \\
\hline \multicolumn{4}{|l|}{ Sex, $n(\%)$} \\
\hline Male & $54(79.4)$ & $51(76.1)$ & $22(78.6)$ \\
\hline Female & $14(20.6)$ & $16(23.9)$ & $6(21.4)$ \\
\hline \multicolumn{4}{|l|}{ Race, $n(\%)$} \\
\hline Caucasian & $68(100)$ & $66(98.5)$ & $28(100)$ \\
\hline Oriental & 0 & $1(1.5)$ & 0 \\
\hline Height (cm), mean (SD) & $172.5(7.5)$ & $171.9(8.0)$ & $172.4(7.2)$ \\
\hline Weight (kg), mean (SD) & $81.4(17.4)$ & $76.6(17.9)$ & $78.5(18.2)$ \\
\hline Body mass index, $\mathrm{kg} / \mathrm{m}^{2}(\mathrm{SD})$ & $27.3(5.3)$ & $25.8(5.2)$ & $26.2(4.9)$ \\
\hline \multicolumn{4}{|l|}{ Smoking history, $n(\%)$} \\
\hline Ex-smoker & $43(63.2)$ & $34(50.7)$ & $16(57.1)$ \\
\hline Current smoker & $25(36.8)$ & $33(49.3)$ & $12(42.9)$ \\
\hline \multicolumn{4}{|l|}{$\begin{array}{l}\text { COPD duration (years), mean } \\
\text { (range) }\end{array}$} \\
\hline Mean (SD) & $7.3(6.58)$ & $6.5(5.94)$ & $7.4(6.14)$ \\
\hline Range & $0-28.4$ & $0.2-31.3$ & $1.6-27.2$ \\
\hline $\mathrm{FEV}_{1} \%$ predicted, mean (SD) & $52.1(10.4)$ & $53.8(11.0)$ & $53.9(12.0)$ \\
\hline $\mathrm{FEV}_{1} \%$ reversibility, mean (SD) & $12.7(10.3)$ & $11.5(9.7)$ & $11.2(10.2)$ \\
\hline \multicolumn{4}{|l|}{$\begin{array}{l}\text { Salbutamol use during run-in } \\
\text { phase* }^{*} \text { (puffs/day), } n(\%)\end{array}$} \\
\hline Missing & 0 & $1(1.5)$ & 0 \\
\hline None & $12(17.6)$ & $11(16.4)$ & $3(10.7)$ \\
\hline$<1$ & $11(16.2)$ & $9(13.4)$ & $4(14.3)$ \\
\hline $1-2$ & $12(17.6)$ & $15(22.4)$ & $9(32.1)$ \\
\hline $3-6$ & $23(33.8)$ & $24(35.8)$ & $6(21.4)$ \\
\hline$>6$ & $10(14.7)$ & $7(10.4)$ & $6(21.4)$ \\
\hline \multicolumn{4}{|c|}{ *i.e. between screening and the first treatment visit. } \\
\hline No statistically significant differen & between treatment $\varsigma$ & & \\
\hline
\end{tabular}


Table 2

Number (\%) of patients with AEs overall and by primary system organ class (Safety population)

\begin{tabular}{|c|c|c|c|}
\hline & $\begin{array}{c}\text { Indacaterol } \\
400 \mu \mathrm{g} \\
n(\%) \\
\end{array}$ & $\begin{array}{c}\text { Indacaterol } \\
800 \mu \mathrm{g} \\
n(\%) \\
\end{array}$ & $\begin{array}{c}\text { Placebo } \\
n(\%)\end{array}$ \\
\hline \multicolumn{4}{|l|}{ Patients studied } \\
\hline Total no. of patients & 68 & 67 & 28 \\
\hline Total no. with AEs & $24(35.3)$ & $34(50.7)$ & $7(25.0)$ \\
\hline \multicolumn{4}{|l|}{ Primary system organ class } \\
\hline $\begin{array}{l}\text { Respiratory, thoracic and } \\
\text { mediastinal disorders* (excl. } \\
\text { infections) }\end{array}$ & $17(25.0)$ & $20(29.9)$ & $4(14.3)$ \\
\hline Infections and infestations & $4(5.9)$ & $5(7.5)$ & $3(10.7)$ \\
\hline Gastrointestinal disorders & $3(4.4)$ & $2(3.0)$ & \\
\hline Ear and labyrinth disorders & $2(2.9)$ & 0 & 0 \\
\hline Nervous system disorders & $2(2.9)$ & $6(9.0)$ & $1(3.6)$ \\
\hline $\begin{array}{l}\text { General disorders and } \\
\text { administration site conditions }\end{array}$ & $1(1.5)$ & $3(4.5)$ & 0 \\
\hline Psychiatric disorders & $1(1.5)$ & $2(3.0)$ & 0 \\
\hline $\begin{array}{l}\text { Skin and subcutaneous tissue } \\
\text { disorders }\end{array}$ & $1(1.5)$ & $1(1.5)$ & $1(3.6)$ \\
\hline Vascular disorders & $1(1.5)$ & 0 & 0 \\
\hline Cardiac disorders & 0 & $1(1.5)$ & 0 \\
\hline Hepatobiliary disorders & 0 & $1(1.5)$ & 0 \\
\hline Investigations & 0 & $1(1.5)$ & $1(3.6)$ \\
\hline $\begin{array}{l}\text { Musculoskeletal and connective } \\
\text { tissue disorders }\end{array}$ & 0 & $2(3.0)$ & 0 \\
\hline Renal and urinary disorders & 0 & $1(1.5)$ & 0 \\
\hline
\end{tabular}

*The category of respiratory, thoracic and mediastinal disorders included: chronic obstructive airways disease, exacerbated; cough; dry throat; dyspnoea; dyspnoea, exertional; epistaxis; rhinitis seasonal; throat irritation 
Table 3

Cardiovascular assessments (safety population)

\begin{tabular}{|c|c|c|c|}
\hline & $\begin{array}{c}\text { Indacaterol } 400 \mu \mathrm{g} \\
(n=68)\end{array}$ & $\begin{array}{c}\text { Indacaterol } 800 \mu \mathrm{g} \\
(n=67)\end{array}$ & $\begin{array}{c}\text { Placebo } \\
(n=28)\end{array}$ \\
\hline \multicolumn{4}{|l|}{ Pulse rate (b.p.m.), mean (SD) } \\
\hline Predose, Day 1 (baseline) & $75.0(13.30)$ & $75.4(10.04)$ & $76.1(11.42)$ \\
\hline 1 hour post-dose, Day 1 & $71.1(9.96)$ & $72.8(10.25)$ & $70.2(8.92)$ \\
\hline Predose, Day 14 & $74.2(11.96)$ & $75.5(9.85)$ & $76.4(14.24)$ \\
\hline 1 hour post-dose, Day 14 & $71.2(10.54)^{\dagger}$ & $74.4(8.88)$ & $71.1(11.88)$ \\
\hline Predose, Day 28 & $73.4(12.44)^{\dagger}$ & $76.7(10.62)$ & $76.2(10.31)$ \\
\hline 1 hour post-dose, Day 28 & $72.2(11.46)$ & $74.2(8.93)$ & $75.9(10.09)$ \\
\hline Maximum post-baseline & $78.7(12.08)$ & $81.5(9.84)$ & $80.8(12.14)$ \\
\hline \multicolumn{4}{|c|}{ Systolic blood pressure $(\mathrm{mmHg})$, mean (SD) } \\
\hline Predose, Day 1 (baseline) & $129.9(15.02)$ & $130.6(17.05)$ & $133.2(14.21)$ \\
\hline 1 hour post-dose, Day 1 & $130.8(15.60)$ & $128.0(15.02)$ & $134.3(14.11)$ \\
\hline Predose, Day 14 & $129.7(16.43)$ & $129.2(17.59)$ & $133.9(22.05)$ \\
\hline 1 hour post-dose, Day 14 & $129.6(15.94)$ & $126.0(15.74)^{*}$ & $136.0(19.38)$ \\
\hline Predose, Day 28 & $132.0(16.77)$ & $128.8(17.09)$ & $132.4(15.61)$ \\
\hline 1 hour post-dose, Day 28 & $129.6(15.82)$ & $126.1(15.50)$ & $131.1(11.77)$ \\
\hline Maximum post-baseline & $139.2(15.30)$ & $137.5(16.60)$ & $144.4(16.73)$ \\
\hline \multicolumn{4}{|c|}{ Diastolic blood pressure, $(\mathrm{mmHg})$, mean $(\mathrm{SD})$} \\
\hline Predose, Day 1 (baseline) & $79.9(10.53)$ & $78.7(10.04)$ & $81.5(9.73)$ \\
\hline 1 hour post-dose, Day 1 & $80.4(9.77)$ & $77.5(9.04)$ & $80.5(8.57)$ \\
\hline Predose, Day 14 & $79.2(11.43)$ & $78.5(8.88)$ & $81.4(12.32)$ \\
\hline 1 hour post-dose, Day 14 & $77.7(11.01)^{*}$ & $77.1(8.01)$ & $82.2(9.63)$ \\
\hline Predose, Day 28 & $80.5(11.47)^{\dagger}$ & $76.5(9.02)$ & $79.2(10.16)$ \\
\hline 1 hour post-dose, Day 28 & $78.5(10.14)$ & $75.5(9.31)$ & $79.3(8.39)$ \\
\hline Minimum post-baseline & $74.0(9.41)$ & $71.9(8.23)$ & $75.2(9.48)$ \\
\hline
\end{tabular}


Table 4

Mean (SD) QTc interval values (using both Bazett's and Fridericia's formulae) (Safety population)

Indacaterol $400 \mu \mathrm{g} \quad$ Indacaterol $800 \mu \mathrm{g} \quad$ Placebo

$(n=68) \quad(n=67) \quad(n=28)$

\begin{tabular}{llll}
\hline \multicolumn{2}{l}{ QTc interval (Bazett's; ms), mean (SD) } & & \\
Predose, Day 1 (baseline) & $411.9(20.15)$ & $416.7(23.16)$ & $419.4(22.29)$ \\
1 hour post-dose, Day 1 & $408.0(22.31)$ & $413.1(23.31)$ & $412.0(21.11)$ \\
Predose, Day 14 & $412.8(21.53)$ & $414.9(26.81)$ & $418.3(22.54)$ \\
1 hour post-dose, Day 14 & $408.9(21.54)$ & $416.8(23.17)$ & $414.2(21.86)$ \\
Predose, Day 28 & $412.1(19.94)$ & $416.7(22.75)$ & $421.7(27.60)$ \\
1 hour post-dose, Day 28 & $410.6(22.39)$ & $411.7(26.56)$ & $418.1(22.69)$ \\
Maximum post-baseline & $424.8(20.39)$ & $431.8(20.92)$ & $433.7(21.51)$ \\
QTc interval (Fridericia's; ms), mean (SD) & & \\
Predose, Day 1 (baseline) & $401.0(19.11)$ & $403.1(19.27)$ & $406.7(22.01)$ \\
1 hour post-dose, Day 1 & $400.8(20.39)$ & $403.0(19.22)$ & $404.0(19.21)$ \\
Predose, Day 14 & $401.8(19.92)$ & $402.0(22.60)$ & $404.4(19.16)$ \\
1 hour post-dose, Day 14 & $400.5(20.67)$ & $404.5(19.93)$ & $406.2(21.24)$ \\
Predose, Day 28 & $400.5(16.45)$ & $402.1(19.33)$ & $407.8(24.44)$ \\
1 hour post-dose, Day 28 & $401.1(19.22)$ & $399.2(22.98)$ & $406.1(19.65)$ \\
Maximum post-baseline & $412.6(19.20)$ & $416.3(18.30)$ & $419.3(20.34)$ \\
\hline
\end{tabular}

No statistically significant difference between any treatment group at any timepoint 
Table 5

Mean (SD) serum potassium and blood glucose (Safety population)

$\begin{array}{ccc}\text { Indacaterol } 400 \mu \mathrm{g} & \text { Indacaterol } 800 \mu \mathrm{g} & \text { Placebo } \\ (n=68) & (n=67) & (n=28)\end{array}$

\begin{tabular}{|c|c|c|c|}
\hline \multicolumn{4}{|c|}{ Serum potassium $(\mathrm{mmol} / \mathrm{l})$, mean $(\mathrm{SD})$} \\
\hline Predose, Day 1 (baseline) & $4.41(0.414)$ & $4.46(0.332)$ & $4.42(0.378)$ \\
\hline 1 hour post-dose, Day 1 & $4.49(0.449)$ & $4.41(0.361)^{\star \dagger}$ & $4.55(0.371)$ \\
\hline Predose, Day 14 & $4.44(0.425)$ & $4.36(0.314)$ & $4.45(0.324)$ \\
\hline 1 hour post-dose, Day 14 & $4.44(0.367)$ & $4.39(0.417)$ & $4.54(0.307)$ \\
\hline Predose, Day 28 & $4.45(0.436)$ & $4.40(0.372)$ & $4.42(0.362)$ \\
\hline 1 hour post-dose, Day 28 & $4.45(0.409)$ & $4.40(0.353)$ & $4.42(0.360)$ \\
\hline Minimum post-baseline & $4.21(0.352)$ & $4.16(0.287)$ & $4.19(0.244)$ \\
\hline \multicolumn{4}{|c|}{ Blood glucose (mmol/l), mean (SD) } \\
\hline Predose, Day 1 (baseline) & $5.29(1.424)$ & $5.10(1.165)$ & $5.28(1.203)$ \\
\hline 1 hour post-dose, Day 1 & $5.37(1.274)$ & $5.35(1.447)$ & $5.04(0.986)$ \\
\hline Predose, Day 14 & $5.36(1.128)$ & $5.02(1.142)^{*}$ & $5.78(1.983)$ \\
\hline 1 hour post-dose, Day 14 & $5.39(1.361)$ & $5.14(0.674)$ & $5.24(1.425)$ \\
\hline Predose, Day 28 & $5.25(1.129)$ & $5.33(1.299)$ & $5.43(1.223)$ \\
\hline 1 hour post-dose, Day 28 & $5.31(1.424)$ & $5.27(0.883)$ & $5.19(0.940)$ \\
\hline Maximum post-baseline & $6.17(1.667)$ & $6.17(1.672)$ & $6.15(2.004)$ \\
\hline
\end{tabular}

Central laboratory lower limit of normal for serum potassium was $3.5 \mathrm{mmol} / \mathrm{l}$, and upper limit of normal for blood glucose was $7.77 \mathrm{mmol} / \mathrm{l}$

${ }^{*} p<0.05$ vs placebo; ${ }^{\dagger} p<0.05$ vs indacaterol $400 \mu \mathrm{g}$ 
Table 6

Mean (SD) FVC and $\mathrm{FEF}_{25-75 \%}$ (Safety population)

Indacaterol $400 \mu \mathrm{g} \quad$ Indacaterol $800 \mu \mathrm{g} \quad$ Placebo

$(n=68)$

$(n=67)$

$(n=28)$

FVC (I), mean (SD)

Predose, Day 1 (baseline)

$3.04(0.748)$

$2.98(0.687)$

$3.01(0.699)$

30 min post-dose, Day 1

$3.40(0.818)$

$3.29(0.782)$

$3.08(0.658)$

Predose, Day 14

$3.27(0.793)$

$3.24(0.770)$

$2.99(0.676)$

30 min post-dose, Day 14

$3.39(0.859)$

$3.35(0.787)$

$2.99(0.690)$

Predose, Day 28

$3.25(0.807)$

$3.20(0.795)$

$2.92(0.728)$

30 min post-dose, Day 28

$3.36(0.835)$

$3.26(0.848)$

$3.14(0.919)$

$\mathrm{FEF}_{25-75 \%}(\mathrm{l} / \mathrm{sec})$, mean (SD)

Predose, Day 1 (baseline)

$0.64(0.288)$

$0.68(0.305)$

$0.72(0.385)$

30 min post-dose, Day 1

$0.79(0.385)$

$0.85(0.369)$

$0.70(0.354)$

Predose, Day 14

$0.75(0.328)$

$0.79(0.356)$

$0.70(0.360)$

30 min post-dose, Day 14

$0.82(0.380)$

$0.83(0.395)$

$0.70(0.399)$

Predose, Day 28

$0.78(0.333)$

$0.80(0.387)$

$0.72(0.358)$

30 min post-dose, Day 28

$0.83(0.383)$

$0.86(0.404)$

$0.81(0.430)$ 
Fig. 1. Mean ( \pm SEM) $F E V_{1}$ over time (Safety population) 
$\square-\square$ Indacaterol $400 \mu \mathrm{g}(n=68) \quad \bigcirc \bigcirc$ Indacaterol $800 \mu \mathrm{g}(n=67)$ -A Placebo $(n=28)$

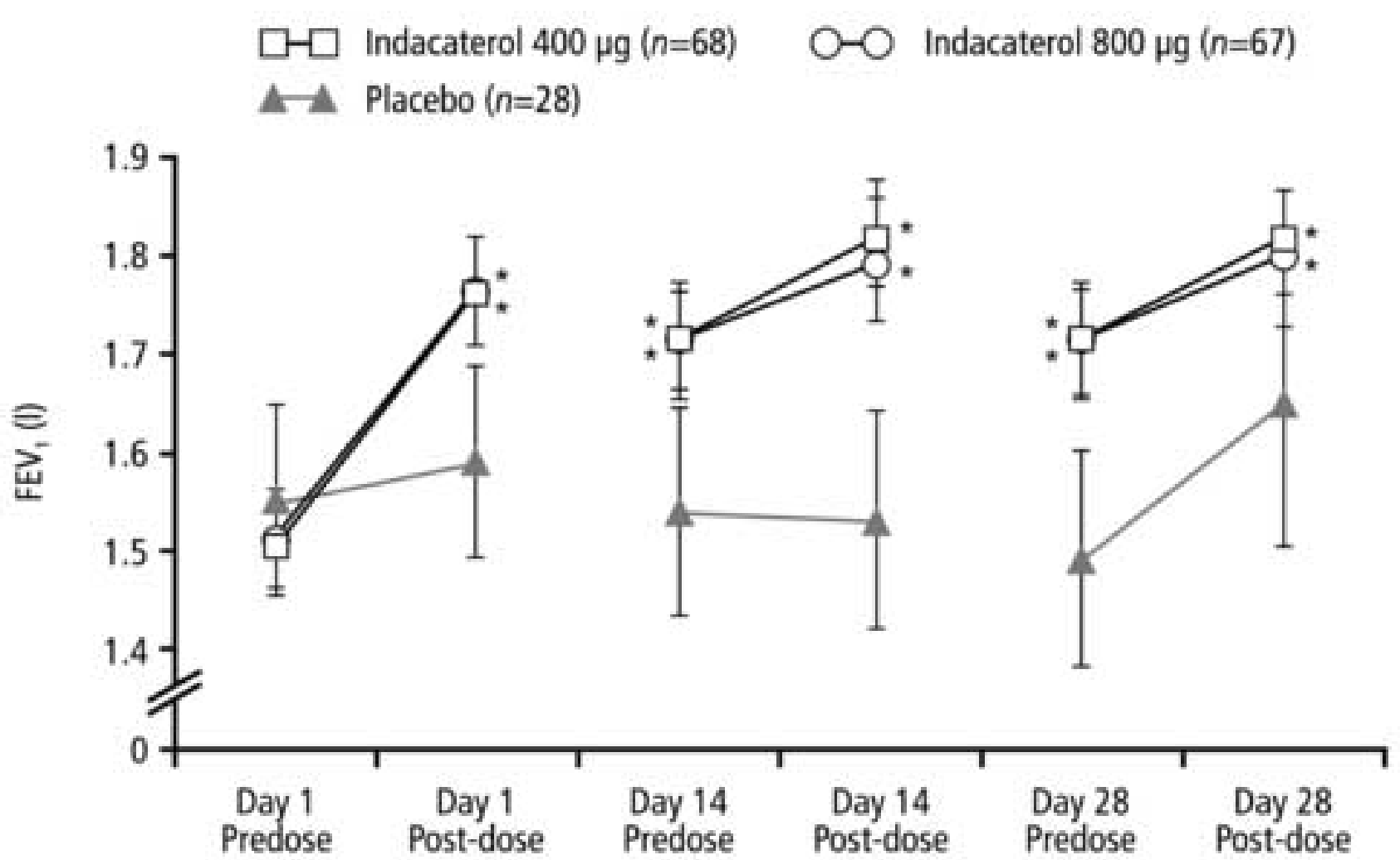

${ }^{*} \mathrm{p}<0.01$ versus placebo 